\title{
Comparative Changes of Lipogenic-Related Enzyme Activities by Dietary Glycerol Tricaprylate, Tricaprate, Trilaurate and Trioleate in Rat Liver and Adipose Tissues
}

\author{
Shin-ichiro TORII, Seong Gu HWANG, \\ Tohru MATSUI, and Hideo YANO \\ Faculty of Agriculture, Kyoto University, Sakyo-ku, \\ Kyoto-shi 606-01
}

(Received January 5, 1995)

\begin{abstract}
The present study was undertaken to investigate the effects of the carbon chain length of dietary medium chain triacylglycerols on lipogenic-related enzyme activities in growing rats. Twenty-four Wistar strain male rats ( 8 weeks old) were allotted to 4 groups and fed the diets containing glycerol tri-homogeneous fatty acid $(260 \mathrm{~g} / \mathrm{kg}$ diet $)$ composed of only caprylic acid (C $8: 0)$, capric acid (C 10:0), lauric acid (Cl2 :0) or oleic acid (C 18;1). After four weeks, the activities of three lipogenic-related enzymes (glucose-6-phosphate dehydrogenase, G-6-PDH ; citrate cleavage enzyme, CCE ; and malic enzyme, ME) in liver and two adipose depots (perirenal and epididymal) were measured. Feeding of $\mathrm{C} 8: 0$ diet resulted in significantly higher G-6-PDH and $\mathrm{CCE}$ activities in the liver than $\mathrm{C} 10: 0$ feeding. In perirenal adipose tissue, G-6-PDH and ME activities were higher in $\mathrm{C} 8: 0$ group than those in the other three groups. The activity of CCE in this adipose depot was lower in $C 8: 0$ group than in $C 10: 0$ and $C 12: 0$ groups. In epididymal adipose tissue, activities of G-6-PDH and ME were lower in C 8:0 group than in $\mathrm{C} 12: 0$ group. Fatty acid composition of perirenal adipose tissue demonstrated that significant amount of dietary $\mathrm{C} 10: 0$ and $\mathrm{C} 12: 0$ fatty acids was directly incorporated into adipose tissue, whereas $\mathrm{C} 8: 0$ deposition was too small to be detected. These results suggest that dietary $\mathrm{C} 8: 0, \mathrm{C} 10: 0$ and $\mathrm{C}_{12}: 0$ fatty acids differently affect lipogenic-related enzyme activity in both liver and adipose tissues in rats.
\end{abstract}

Anim. Sci. Technol. (Jpn.) 67 (5) : 430-438, 1996

Key words: Medium chain triacylglycerol, Lipogenic-related enzyme activity, Liver, adipose tissue, Rat

A number of studies have been undertaken to investigate the effects of dietary medium chain triacylglycerols (MCTs) on lipid metabolism. It has been reported that, dietary MCTs reduce serum cholesterol and serum triacylglycerol level ${ }^{21,25)}$ and fat accumulation in adipose tissue ${ }^{5,13)}$ than dietary long chain triacylglycerols (LCTs).
It has been demonstrated that dietary triacylglycerols suppress lipogenic and lipogenic -related enzyme activities in liver ${ }^{3,5)}$ and adipose tissue ${ }^{13)}$ whereas MCT is less effective than LCT $^{25)}$. Medium chain triacylglycerols which were used in these studies contained various medium chain fatty acids (MCFAs), such as caprylic acid (C $8: 0)$, capric acid (C 10 : 
Dietary MCT and Lipogenic-Related Enzyme Activity

$0)$ and lauric acid (C12:0). It is still not known whether C 8:0, C $10: 0$ and $\mathrm{C} 12: 0$ fatty acids identically affect lipogenic-related enzyme activities or not. The present study was undertaken to investigate the influence of the carbon chain length of dietary MCT on lipogenic-related enzyme activities in liver and adipose tissues by feeding each glycerol trihomogeneous MCFAs in rats.

\section{Materials and Methods}

\section{Animals and diets}

Twenty-four Wistar strain male rats, aged 5 weeks, were purchased from SLC, Inc. (Hamamatsu, Japan) and fed the commercial laboratory chow for 3 weeks to reach $270 \mathrm{~g}$ of body weight. Through the experiment, room temperature and humidity were maintained at $24^{\circ} \mathrm{C}$ and $60 \%$, respectively, with a 12 hours light-dark cycle. Then animals were randomly divided into 4 groups and fed the experimental diets for 4 weeks, which contained MCT or LCT (54\% of total energy) composed of C 8:0, C 10:0, C $12: 0$ or oleic acid (C 18:1), respectively (Table 1 ). Such MCT and LCT contained more than $97 \%$ of synthesized glycerol tri-homogeneous fatty acid and were generously supplied by Kao Co. (Tokyo, Japan). Commercial corn oil was supplemented in each experimental diet $(20 \mathrm{~g} / \mathrm{kg}$ diet) for the source of essential fatty acids. All diets contained $22.3 \mathrm{~kJ} / \mathrm{g}$ of gross energy and $54.2 \%$ of dietary energy was derived from fat, $27.2 \%$ was from protein and $18.6 \%$ was from carbohydrate. As a result, C 18:1 diet contained less content of triacylglycerol compared with the other diets, when expressed as weight basis. Each animal was housed in an individual stainless steel wire cage and fed each experimental diet to take same amount of energy with free access to tap water.

\section{Enzyme assay}

Food deprivation was carried out for 15 hours before slaughter. After the animals were killed by exsanguination from the ab-
Table 1. Composition of experimental diets

\begin{tabular}{|c|c|c|}
\hline Ingredients & $\mathrm{C} 8, \mathrm{C}_{10}, \mathrm{C}_{12}$ & C $18: 1$ \\
\hline & \multicolumn{2}{|c|}{$\mathrm{g} / 100 \mathrm{~g}$} \\
\hline Casein & 21.0 & 21.0 \\
\hline DL-Methionine & 0.3 & 0.3 \\
\hline Corn starch & 10.0 & 10.0 \\
\hline Sucrose & 10.0 & 10.0 \\
\hline Cellulose powder & 25.0 & 27.0 \\
\hline Corn oill & 2.0 & 2.0 \\
\hline Mineral mix ${ }^{2}$ & 4.0 & 4.0 \\
\hline Vitamin $\mathrm{mix}^{3}$ & 1.5 & 1.5 \\
\hline Choline chloride & 0.2 & 0.2 \\
\hline \multirow[t]{2}{*}{ Triacylglycerol ${ }^{4}$} & 26.0 & 24.0 \\
\hline & \multicolumn{2}{|c|}{ Source of energy (\%) } \\
\hline Fat & 54.2 & 54.2 \\
\hline Protein & 27.2 & 27.2 \\
\hline Carbohydrates & 18.6 & 18.6 \\
\hline
\end{tabular}

${ }^{1}$ Commercial corn oil. ${ }^{2,3}$ AIN-76 mineral and vitamin mixtures (Oriental Yeast Co., Tokyo, Japan). " Each triacylglycerol contained more than 97\% of synthesized triacylglycerols (Kao Co., Tokyo, Japan).

dominal aorta under pentobarbital anesthetization, liver, and perirenal and epididymal adipose tissues were collected and washed in icecold physiological saline. After weighing each tissue, $4 \mathrm{~g}$ of the liver or $2 \mathrm{~g}$ of the adipose tissue was homogenized in ice-cold $0.25 \mathrm{M}$ sucrose $/ 1 \mathrm{mM}$ ethylenediaminetetraacetate buffer $(\mathrm{pH}=7.4)$ using a glass-Teflon homogenizer. Homogenate was centrifuged at $9800 \mathrm{rpm}$ at $4^{\circ} \mathrm{C}$ for 15 minutes. Clear intermediate water-soluble phase was centrifuged again at 41000rpm at $4^{\circ} \mathrm{C}$ for 60 minutes. The supernatant was preserved at $-80^{\circ} \mathrm{C}$ until assay for enzyme activities. Glucose-6-phosphate dehydrogenase (G-6-PDH ; EC 1.1.1.49) activity was assayed by the method of Löhr and Waller ${ }^{16)}$, citrate cleavage enzyme (CCE; EC 4.1.3.8) activity by the method of Takeda et $a l^{23}{ }^{23}$, and malic enzyme (ME; EC 1.1.1.40) activity by the method of Ochoa ${ }^{18)}$. Enzyme activities were expressed as rates of disappearance of substrate ( $\mathrm{n} \mathrm{mol} / \mathrm{min}$ ) per mg of protein. Protein content in the supernatant was determined by the method of 
Lowry et al. ${ }^{17)}$.

\section{Fatty acid composition}

Total lipids of perirenal adipose tissue were extracted by the procedure of Folch et al ${ }^{6}$. Methyl-esterification of fatty acid was carried out by the procedure of Stoffel et al..$^{20)}$. The fatty acid composition of methyl esters was determined by gas liquid chromatography (Yanaco G.C. 180, Yanagimoto Seisakusho Co., Kyoto, Japan) using a glass column ( $4 \mathrm{~m} \times 2 \mathrm{~mm}$ i.d.) packed with $5 \%$ Shinchrom E 71 on $80-100$ mesh Shimalite AW (Shinwa Chemical Industries Ltd., Kyoto, Japan). A carrier gas was nitrogen. Injection temperature was maintained at $230^{\circ} \mathrm{C}$ and the oven temperature was programmed to increase from 160 to $240^{\circ} \mathrm{C}$ by $2^{\circ} \mathrm{C} / \mathrm{min}$. Fatty acids were identified by retention time comparison with authentic fatty acid methyl ester standards.

Statistical analysis

Statistical analysis was performed by oneway analysis of variance and differences between dietary groups were determined by Fisher's least significant difference test at $p<$ 0.05 using GLM procedure of SAS ${ }^{19)}$. Differences in fatty acid composition between dietary groups were tested after arcsin transformation.

\section{Results}

Body weight, food intake and final liver weight are shown in Table 2. Final body weight was larger in $\mathrm{C} 10: 0$ group than in $\mathrm{C} 12: 0$ and $\mathrm{C} 18: 1$ groups. Final liver weight was significantly $(p<0.05)$ larger in $\mathrm{C} 10: 0$ group than other three groups.

Weights of perirenal and epididymal adipose tissues are shown in Fig. 1. In both depots, there was no significant difference in tissue weight among the groups of $\mathrm{C} 8: 0-\mathrm{C} 12: 0$. Perirenal adipose tissue weight was significantly $(p<0.05)$ lower in $\mathrm{C} 8: 0$ group than in $\mathrm{C} 18: 1$ group. Epididymal adipose tissue weight was significantly $(\mathrm{p}<0.05)$ lower in $\mathrm{C} 8: 0$ and $\mathrm{C} 12: 0$ groups than in $\mathrm{C} 18: 1$ group but the difference between $\mathrm{C} 10: 0$ and $\mathrm{C}$ $18: 1$ group was not significant in this depot.

Lipogenic-related enzyme activities in liver are shown in Table 3 . The activities of G-6-

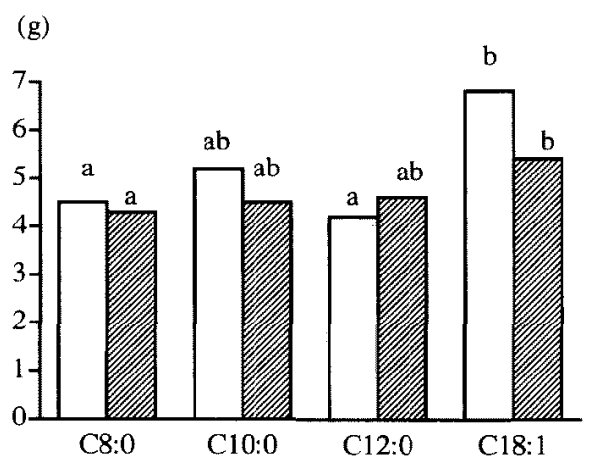

Fig. 1. Weights of perirenal (open bars) and epididymal (hatched bars) adipose tissue in rats fed the different glycerol tri-homogeneous medium- or long-chain fatty acids.

Each bar represents mean for 6 rats.

$\mathrm{a}, \mathrm{b}$ : Different letters within the same anatomical site denote significant differences $(p<0.05)$.

Tahle 2. Body weight, food intake and final liver weight in rats fed the different glycerol trihomogeneous medium- or long-chain fatty acids

\begin{tabular}{lllll}
\hline \hline & & \multicolumn{3}{c}{ Diets } \\
\cline { 2 - 5 } & $\mathrm{C} 8: 0$ & $\mathrm{C} 10: 0$ & $\mathrm{C} 12: 0$ & $\mathrm{C} 18: 1$ \\
\hline Initial body weight $(\mathrm{g})$ & $274 \pm 14$ & $274 \pm 14$ & $274 \pm 14$ & $274 \pm 12$ \\
Final body weight $(\mathrm{g})$ & $327 \pm 5^{\mathrm{ab}}$ & $330 \pm 5^{\mathrm{a}}$ & $315 \pm 5^{\mathrm{b}}$ & $316 \pm 5^{\mathrm{b}}$ \\
Food intake $(\mathrm{g} / 28 \mathrm{~d})$ & $463 \pm 6^{\mathrm{a}}$ & $456 \pm 6^{\mathrm{ab}}$ & $426 \pm 6^{\mathrm{c}}$ & $443 \pm 6^{\mathrm{b}}$ \\
Final liver weight $(\mathrm{g})$ & $8.4 \pm 0.3^{\mathrm{b}}$ & $9.3 \pm 0.3^{\mathrm{a}}$ & $8.4 \pm 0.3^{\mathrm{b}}$ & $7.9 \pm 0.3^{\mathrm{b}}$ \\
\hline
\end{tabular}

a.b.c: Values in the same row with different superscripts are significantly different $(p<0.05)$ 
$\mathrm{PDH}, \mathrm{CCE}$ and $\mathrm{ME}$ in $\mathrm{C} 8: 0$ group was similar to those in $\mathrm{C} 18: 1$ group. The activities of all three enzyme were significantly $(\mathrm{p}<0.05)$ lower in $\mathrm{C} 10: 0$ and $\mathrm{C} 12: 0$ groups than in $\mathrm{C} 18: 1$ group. The activity of G-6-PDH was significantly $(p<0.05)$ higher in $\mathrm{C} 8: 0$ group than in $\mathrm{C} 10: 0$ group but the difference between $\mathrm{C} 8: 0$ and $\mathrm{C} 12: 0$ group was not statistically significant. The activity of $\mathrm{CCE}$ was significantly $(\mathrm{p}<0.05)$ lower in both $\mathrm{C} 10: 0$ and $\mathrm{C} 12: 0$ groups than in $\mathrm{C} 8: 0$ group. The activity of $\mathrm{ME}$ was remarkably lower in $\mathrm{C} 12$ : 0 group than in $\mathrm{C} 8: 0$ and $\mathrm{C} 10: 0$ groups $(\mathrm{p}<$ 0.05).

In perirenal adipose tissue, G-6-PDH and $\mathrm{ME}$ activities were higher $(\mathrm{p}<0.05)$ in $\mathrm{C} 8: 0$ group than in $\mathrm{C} 10: 0$ and $\mathrm{C} 12: 0$ groups (Table 4).
Dietary C 18: 1 markedly suppressed ME activity in this adipose depot. The activity of $\mathrm{CCE}$ was significantly $(p<0.05)$ lower in $C 8: 0$ group than in $\mathrm{C} 10: 0$ and $\mathrm{C} 12: 0$ groups. The activity of this enzyme in $\mathrm{C} 18: 1$ group was almost similar to $\mathrm{C} 8: 0$ group.

In every group, the lipogenic-related enzyme activities were drastically lower in epididymal adipose tissue compared with perirenal adipose tissue (Table 4). The activity of G-6-PDH in epididymal adipose tissue was lower in $\mathrm{C} 8: 0$ group than in $\mathrm{C} 10: 0$ and $\mathrm{C} 12: 0$ groups and was not different between $C 18: 1$ and $C 8: 0$ groups. The activity of $\mathrm{ME}$ was higher in C $12: 0$ group than $\mathrm{C} 8: 0$ group. On the other hand, no difference was found in CCE activities among all groups. The activities of G-6-PDH

Table 3. Lipogenic-related enzyme activities in the fasting state in liver of rats fed the different glycerol tri-homogeneous medium- or long-chain fatty acids for four weeks

\begin{tabular}{lcccc}
\hline & \multicolumn{3}{c}{ Diets } \\
\cline { 2 - 4 } & $\mathrm{C} 8: 0$ & $\mathrm{C} 10: 0$ & $\mathrm{C} 12: 0$ & $\mathrm{C} 18: 1$ \\
\hline & & $(\mathrm{nmol} / \mathrm{min} / \mathrm{mg} \mathrm{protein})$ & \\
G-6-PDH & $15.3 \pm 2.3^{\mathrm{bc}}$ & $8.0 \pm 2.5^{\mathrm{a}}$ & $8.9 \pm 2.3^{\mathrm{ab}}$ & $15.9 \pm 2.3^{\mathrm{c}}$ \\
CCE & $8.0 \pm 0.7^{\mathrm{b}}$ & $5.7 \pm 0.7^{\mathrm{a}}$ & $5.3 \pm 0.7^{\mathrm{a}}$ & $7.6 \pm 0.7^{\mathrm{b}}$ \\
ME & $115 \pm 10^{\mathrm{bc}}$ & $96 \pm 10^{\mathrm{b}}$ & $51 \pm 10^{\mathrm{a}}$ & $128 \pm 10^{\mathrm{c}}$ \\
\hline
\end{tabular}

$a, b, c:$ Values in the same row with different superscripts are significantly different $(p<0.05)$.

G-6-PDH, glucose-6-phosphate dehydrogenase ; CCE, citrate cleavage enzyme ; ME, malic enzyme.

Table 4. Lipogenic-related enzyme activities in the fasting state in perirenal and epididymal adipose tissue of rats fed the different glycerol tri-homogeneous medium-or long-chain fatty acids for four weeks

\begin{tabular}{|c|c|c|c|c|}
\hline & \multicolumn{4}{|c|}{ Diets } \\
\hline & $C 8: 0$ & C 10:0 & $\mathrm{C} 12: 0$ & C 18:1 \\
\hline & \multicolumn{4}{|c|}{ (nmol/min $/ \mathrm{mg}$ protein) } \\
\hline & \multicolumn{4}{|c|}{ Perirenal } \\
\hline $\mathrm{G}-6-\mathrm{PDH}$ & $103.4 \pm 9.8^{b}$ & $69.9 \pm 9.8^{\mathrm{a}}$ & $56.5+9.8^{a}$ & $46.6 \pm 10.7^{a}$ \\
\hline CCE & $12.3 \pm 2.0^{\mathrm{a}}$ & $18.6 \pm 2.0^{6}$ & $25.1 \pm 2.0^{c}$ & $14.4 \pm 2.2^{\mathrm{ab}}$ \\
\hline \multirow[t]{2}{*}{$\mathrm{ME}$} & $175 \pm 13^{d}$ & $118 \pm 13^{c}$ & $77 \pm 13^{b}$ & $31 \pm 14^{\mathrm{a}}$ \\
\hline & \multicolumn{4}{|c|}{ Epididymal } \\
\hline G-6-PDH & $24.4 \pm 5.3^{\mathrm{a}}$ & $43.5 \pm 5.3^{b}$ & 46. $1 \pm 5.3^{\mathrm{h}}$ & $26.3 \pm 5.3^{\text {a }}$ \\
\hline CCE & $12.2 \pm 1.8$ & $12.8 \pm 1.8$ & $14.1 \pm 1.8$ & $10.4 \pm 1.8$ \\
\hline $\mathrm{ME}$ & $29 \pm 4^{b}$ & $33 \pm 4^{b c}$ & $40 \pm 4^{c}$ & $18 \pm 4^{3}$ \\
\hline
\end{tabular}

$a, b, c, d$ : Values in the same row with different superscripts are significantly different $(p<0.05)$.

G-6-PDH, glucose-6-phosphate dehydrogenase ; CCE, citrate cleavage enzyme ; $\mathrm{ME}$, malic enzyme. 
and $\mathrm{ME}$ were not different between the rats fed the $\mathrm{C} 10: 0$ and $\mathrm{C} 12: 0$ diets. The activity of $\mathrm{ME}$ was lower in C18:1 group than in any of MCT-fed groups.

As shown in Table $5, \mathrm{C} 8: 0$ content in perirenal adipose tissue was too small to be determined in $\mathrm{C} 8$ :0-fed rats in spite of its high dietary level. On the other hand, $\mathrm{C} 10: 0$ accounted for approximately $10 \%$ of total fatty acids in the adipose tissue of $\mathrm{C} 10: 0$-fed rats. In rats fed the $\mathrm{C} 12: 0$ diet, $\mathrm{C} 12: 0$ content was remarkably high (18.2\%). The content of palmitic acid, which is the major end product of biosynthesis of fatty acid, was higher in C $8: 0$ group than in $\mathrm{C} 10: 0$ and $\mathrm{C} 12: 0$ groups. In addition, the contents of palmitoleic, oleic and linoleic acids were significantly $(p<0.05)$ higher in $\mathrm{C} 8: 0$ group than in $\mathrm{C} 12: 0$ group. The rats fed $\mathrm{C} 10: 0$ showed intermediate levels of the contents of these long-chain fatty acids between $\mathrm{C} 8: 0$ - and $\mathrm{C} 12: 0$-fed rats. Oleic acid content was drastically high in $\mathrm{C} 18: 1$ group. In addition, eicosamonoenoic acid content of $\mathrm{C} 18: 1$ group was significantly $(\mathrm{p}<0.05)$ higher than that of any other group.

\section{Discussion}

It has been well known that dietary fat inhibits hepatic and adipose tissue lipogenesis ${ }^{8}$. Acetate incorporation into fatty acids was significantly inhibited in liver slice from the rats fed corn oil, vegetable oil, hydrogenated

Table 5. Fatty acid composition of perirenal adipose tissue in rats fed the different glycerol trihomogeneous medium- or long-chain fatty acids

\begin{tabular}{|c|c|c|c|c|}
\hline & \multicolumn{4}{|c|}{ Diets } \\
\hline & $\mathrm{C} 8: 0$ & $\mathrm{C} 10: 0$ & $\mathrm{C} 12: 0$ & $\mathrm{C} 18: 1$ \\
\hline & \multicolumn{4}{|c|}{$\mathrm{g} / 100 \mathrm{~g}$ fatty acids } \\
\hline $\mathrm{C} 8: 0$ & $\operatorname{Tr}$ & $\operatorname{Tr}$ & $\operatorname{Tr}$ & $\operatorname{Tr}$ \\
\hline C $10: 0$ & $1.4 \pm 0.2^{\mathrm{b}}$ & $9.8 \pm 0.4^{c}$ & $1.2 \pm 0.1^{\mathrm{b}}$ & $0.1 \pm 0.0^{\mathrm{a}}$ \\
\hline C $12: 0$ & 1. $4 \pm 0.1^{\mathrm{ab}}$ & $1.9 \pm 0.0^{\mathrm{b}}$ & $18.2 \pm 0.9^{\circ}$ & $0.6 \pm 0.2^{\mathrm{a}}$ \\
\hline C $14: 0$ & $5.8 \pm 0.3^{b c}$ & $5.5 \pm 0.2^{b}$ & $7.0 \pm 0.3^{c}$ & $3.1 \pm 0.2^{a}$ \\
\hline $\mathrm{C} 14: 1(\mathrm{n}-7)$ & $0.6 \pm 0.1$ & $0.4 \pm 0.1$ & $0.6 \pm 0.0$ & $0.1 \pm 0.0$ \\
\hline C $15: 0$ & $0.8 \pm 0.1^{b}$ & $1.0 \pm 0.1^{\mathrm{c}}$ & $0.9 \pm 0.0^{b c}$ & $0.6 \pm 0.1^{a}$ \\
\hline C 16:0 & $23.4 \pm 0.6^{c}$ & $20.6 \pm 0.5^{b}$ & $16.9 \pm 0.4^{a}$ & $15.8 \pm 0.7^{\mathrm{a}}$ \\
\hline $\mathrm{C} 16: 1(\mathrm{n}-7)$ & $11.2 \pm 0.7^{\mathrm{c}}$ & $8.7 \pm 0.4^{\mathrm{ab}}$ & $7.7 \pm 0.2^{\mathrm{a}}$ & $9.5 \pm 0.4^{\mathrm{b}}$ \\
\hline $\mathrm{C} 17: 0$ & $0.4 \pm 0.2^{\mathrm{a}}$ & $0.9 \pm 0.0^{c}$ & $0.7 \pm 0.0^{\mathrm{b}}$ & $0.9 \pm 0.1^{c}$ \\
\hline Iso C $18: 0$ & $1.0 \pm 0.1^{a}$ & $1.0 \pm 0.5^{\mathrm{a}}$ & $0.8 \pm 0.1^{\mathrm{a}}$ & $2.0 \pm 0.2^{b}$ \\
\hline C 18:0 & $7.7 \pm 0.3^{b}$ & $8.4 \pm 0.5^{b}$ & $5.7 \pm 0.2^{\mathrm{a}}$ & $6.5 \pm 0.2^{\mathrm{a}}$ \\
\hline$C 18: 1(n-9)$ & $24.2 \pm 0.5^{b}$ & $20.1 \pm 0.4^{\mathrm{a}}$ & 17. $9 \pm 0.5^{\mathrm{a}}$ & $40.2 \pm 1.6^{c}$ \\
\hline C $18: 2(n-6)$ & $17.3 \pm 0.7^{b}$ & $16.9 \pm 0.4^{\mathrm{b}}$ & $15.1 \pm 0.5^{\mathrm{a}}$ & $16.0 \pm 0.3^{\mathrm{ab}}$ \\
\hline $\mathrm{C} 18: 3(\mathrm{n}-3)$ & $1.1 \pm 0.3^{3}$ & $1.3 \pm 0.6^{\mathrm{b}}$ & $0.8 \pm 0.2^{b}$ & $0.1 \pm 0.0^{\mathrm{s}}$ \\
\hline $\mathrm{C} 20: 0$ & $0.5 \pm 0.1$ & $0.5 \pm 0.1$ & $0.3 \pm 0.0$ & $0.3 \pm 0.1$ \\
\hline$C 20: 1(n-9)$ & $1.6 \pm 0.4^{\mathrm{a}}$ & $1.8 \pm 0.8^{a}$ & $2.2 \pm 0.2^{\mathrm{a}}$ & $4.1 \pm 0.2^{b}$ \\
\hline $\mathrm{C} 20: 4(n-6)$ & $0.3 \pm 0.1^{a b}$ & $0.5 \pm 0.1^{\mathrm{b}}$ & $0.2 \pm 0.0^{\mathrm{a}}$ & $0.2 \pm 0.1^{\mathrm{a}}$ \\
\hline SFA & $42.3 \pm 0.7^{b}$ & $49.4 \pm 0.6^{c}$ & $51.2 \pm 1.0^{c}$ & $31.3 \pm 0.2^{a}$ \\
\hline MUFA & $37.8 \pm 0.7^{b}$ & $31.0 \pm 1.1^{\mathrm{a}}$ & $28.7 \pm 0.6^{a}$ & $53.9 \pm 1.1^{\mathrm{c}}$ \\
\hline PUFA & 18. $2 \pm 0.6^{\circ}$ & $18.4 \pm 0.9^{\mathrm{b}}$ & 16. $4 \pm 0.9^{\mathrm{a}}$ & $16.3 \pm 0.3^{\mathrm{a}}$ \\
\hline SFA/PUFA & $0.75 \pm 0.03^{b}$ & $0.94 \pm 0.01^{2}$ & $1.08 \pm 0.01^{d}$ & $0.45 \pm 0.01^{\mathrm{a}}$ \\
\hline
\end{tabular}

$a, b, c, d:$ Values in the same row with different superscripts are significantly different $(\mathrm{p}<0.05)$.

Tr, trace; SFA, saturated fatty acid; MUFA, monounsaturated fatty acid; PUFA, polyunsaturated fatty acid. 
vegetable oil or lard ${ }^{9)}$. Leveille ${ }^{15)}$ showed that incorporation of acetate or glucose into fatty acids in vitro was reduced in the epididymal adipose tissue of rats as dietary level of hydrogenated vegetable oil was increased from $10 \%$ to $30 \%$. Furthermore, it has been suggested that, the inhibition of lipogenesis by dietary fat is not due to the reduction of carbohydrate intake ${ }^{24)}$. In these studies, dietary fat was mainly composed of LCTs. On the other hand, it has been reported that dietary MCT is markedly less effective than LCT in suppression of lipogenesis in liver and adipose tissue of rats $^{25)}$. MCT-rich diet (34 or $37 \mathrm{~g} / 100 \mathrm{~g}$ diet) diminished lipogenic-related enzyme activity compared with low-fat diet ${ }^{\hat{6}, 14)}$. In contrast, Takase $e$ t $a l_{.}{ }^{22)}$ reported stimulation of malic enzyme activity in liver of rats by dietary MCT $(13 \mathrm{~g} / 100 \mathrm{~g}$ diet). Dietary level of MCT used in the present study was $26 \mathrm{~g} / 100 \mathrm{~g}$ diet but effects in more moderate condition (10 to $15 \mathrm{~g}$ / $100 \mathrm{~g}$ diet) remains to be tested.

Dietary long-chain fatty acids are thought to be directly incorporated into adipose tissues, where these fatty acids inhibit lipogenesis. Foufelle et al. reported that medium-chain and long-chain fatty acids did not have the same inhibitory potency for the activity and the gene expression of acetyl-CoA carboxylase and fatty-acid synthase in liver and adipose tissue $^{7)}$. In the present study, lipogenic-related enzyme activities in the liver of $\mathrm{C} 18: 1$-fed rats were comparable to rats fed $\mathrm{C} 8: 0$ diet, while $\mathrm{C} 18: 1$ diet suppressed lipogenic-related enzyme activities in both perirenal and epididymal adipose tissues compared with MCT diets. It has been reported that fatty acids of the $n-9$ family such as oleic acid did not suppress the expression of genes coding for lipogenic enzymes in hepatocyte $\mathrm{e}^{4)}$. The present results suggested that liver and adipose tissue lipogenesis might be regulated by dietary fats in different manner.

In the present study, $\mathrm{C} 10: 0$ or $\mathrm{C} 12: 0$ group showed significantly lower lipogenic-related enzyme activities than $C 8: 0$ group in liver. It is well documented that MCFAs are easily absorbed and transported via portal vein into liver. MCFAs then can rapidly pass through inner mitochondrial membrane in hepatocytes, due to independence on action of carnitine. Because of these metabolic pathway, it has been suggested that MCFAs can be easily $\beta$ oxidized in liver, and they are utilized for energy as rapidly as glucose ${ }^{\mathrm{l}}$. In addition, C 8 : 0 has been suggested to be metabolized in mitochondria more rapidly compared with the other MCFAs, such as $\mathrm{C} 10: 0$ and $\mathrm{C} 12: 0^{1}$, which may have affected hepatic energy flux followed by shift toward lipogenic state. These unique properties of C 8:0 fatty acid resulted in markedly less effect on suppression of lipogenic-related enzyme activities ${ }^{10,25)}$. According to the fatty acid composition in perirenal adipose tissue, it was shown that C 10:0 and C 12:0 were largely incorporated into adipose depot in rats fed $\mathrm{C} 10: 0$ and $\mathrm{C} 12$ : 0 diets, respectively. However, C 8:0 did not accumulate in the adipose depot of $\mathrm{C} 8: 0$-fed rats (Table 5). These results suggest that relatively large amount of dietary $\mathrm{C} 10: 0$ and C 12:0 may be transported to adipose tissues via lymphatic circulation in the form of chylomicron. Therefore, the amount of $\mathrm{C} 10: 0$ (in C 10:0 group) or C 12:0 (in C 12:0 group) oxidized in liver should have been decreased compared with that of $\mathrm{C} 8: 0$ in $\mathrm{C} 8: 0$ group in the present study, which may account for lower lipogenic-related enzyme activity in liver.

Interestingly, lipogenic-related enzyme activities of epididymal adipose tissue were drastically low in every group compared with those of perirenal adipose tissue. It is considered that fat deposition in epididymal adipose tissue would be less active than perirenal adipose tissue in our experimental condition. It is not clear why there is such different lipogenic performance between these adipose depots. However, maturing stage of adipose 


\section{TORII, HWANG, MATSUI and YANO}

tissue may have been one of factors that induced the difference of lipogenic-related enzyme activities between depots.

In the present experiment, enzyme activities were measured in the animals of fasted condition. It has been reported that lipogenic-related enzyme activities vary greatly by feeding or fasting ${ }^{11,12)}$. The effects of each MCTs on lipogenic-related enzyme activities in the fed state remain to be discussed.

Fatty acid profile showed a good reflection of de novo lipogenesis. The composition of palmitic acid, the major end product of biosynthesis of fatty acid, was high in C $8: 0$ group (Table 5). In addition, it is assumable that higher contents of palmitoleic $(\mathrm{C} 16: 1)$ and oleic (C 18:1) acids in C 8:0 group may be resulted from the desaturation and chain elongation of palmitic acid. Some authors have proposed that $\Delta 9$-desaturase, which may affect fatty acid composition in the body, is regulated by different dietary fatty acids ${ }^{2}$. The contents of C 16:0, C 16:1 and C 18:1 was also high in the epididymal adipose tissue of C 8: 0 group (data not shown). These results suggest that the increase of composition of these endogenous fatty acids in adipose tissues by $\mathrm{C} 8: 0$ feeding is attributed in part to the stimulation of hepatic, rather than adipose tissue, lipogenesis.

In conclusion, the present data suggested that $\mathrm{C} 8: 0, \mathrm{C} 10: 0$ and $\mathrm{C} 12: 0$ fatty acids, so called MCT, should be reevaluated as different nutrients one another in view of its metabolic consequences, at least, in the point of different lipogenic effects. Furthermore, there may be tissue-specific regulatory mechanism of lipogenesis by the chain length of fatty acid. Lipogenic response can be varied, with its anatomical site even in the same kind of tissues.

\section{References}

1) Bach AC, Babayan VK. Medium-chain triglycerides : an update. Am. J. Clin. Nutr., 36 :
950-962. 1982.

2) Buller KJ, Enser M. The effect of food intake and dietary fatty acids on activity of stearoylCoA $\Delta^{9}$ desaturase in pig adipose tissue. J. Agric. Sci. (Camb.), 106 : 601-609. 1986.

3) Chanez M, Joyeux BB, Armaud MJ, Peret J. Metabolic effects in rats of a diet with a moderate level of medium-chain triglycerides. J. Nutr., $121: 585^{-594 . ~} 1991$.

4) Clarke SD, Jump DB. Regulation of hepatic gene expression by dietary fats : A unique role for polyunsaturated fatty acids. In : Bardanier CD, Hargrove JL (Ed.) CRC Press Reviews, CRC Press, Boca Raton, FL. 1992.

5) Crozier G, Bois-Joyeux B, Chanez M, Girard J, Peret J. Metabolic effects induced by longterm feeding of medium-chain triglycerides in the rat. Metabolism, 36: 807-814. 1987.

6) Folch J, Lees M, Sloane Stanley GH. A simple method for the isolation and purification of total lipids from animal tissues. J. Biol. Chem., $226: 497-509.1957$.

7) Foufelle F, Perdereau D, Gouhot B, Ferre P, Girard J. Effect of diets rich in medium-chain and long-chain triglycerides on lipogenicenzyme gene expression in liver and adipose tissue of the weaned rat. Eur. J. Biochem., 208: 381-387. 1992.

8) Herzberg GR. The influence of dietary fatty acid composition on lipogenesis. Adv. Nutr. Res., $5: 221-253.1983$.

9) Hill R, Linazosoro JM, Chevallier F, Charkoff IL. Regulation of hepatic lipogenesis : The infuence of dietary fat. J. Biol. Chem., $233: 305^{-}$ 310. 1958.

10) Hwang SG, Yano H, Kawashima R. The infuence of dietary medium and long chain triglycerides on growth performances and fat deposition in growing rats. J. Nutr. Sci. Vitaminol., 38 : 127-139. 1992.

11) Katsurada A, Iritani N, Fukuda H, Noguchi T, Tanaka $\mathrm{T}$. Influence of diet on the transcriptional and post-transcriptional regulation of malic enzyme induction in the rat liver. Eur. J. Biochem., 168: 487-491. 1987.

12) Katsurada $A$, Iritani N, Fukuda $H$, Matsumura Y, Noguchi T, Tanaka T. Effects of nutrients and insulin on transcriptional and post-transcriptional regulation of glucose-6-phosphate dehydrogenase synthesis in rat liver. Biochim. Biophys. Acta, 1006 : 104-110. 1989.

13) Lavan M, Fornari V, Hashim SA. Ketone metabolism in brain slices from rats with diet 
induced hyperketonemia. J. Nutr., 108:621629. 1978.

14) Lavau MM, Hashim SA. Effect of medium chain triglyceride on lipogenesis and body fat in the rat. J. Nutr., $108: 613-620.1978$.

15) Leveille $G$. Influence of dietary fat level on the enzymatic and lipogenic adaptation in adipose tissue of meal-fed rats. J. Nutr., $91: 267-274$. 1967.

16) Löhr GW, Waller HD. Methods of Enzymatic Analysis., 2nd ed, 636-643. Weinheinad Academic Press. New York. 1974.

17) Lowry OH, Rosebrough NJ, Farr AL, Randall RJ. Protein measurement with the folin phenol reagent. J. Biol. Chem., 193 : 265-275. 1951.

18) Ochoa S. "Malic" Enzyme. Methods Enzymol., $1: 739-753.1955$.

19) SAS. SAS User's Guide, 5th ed., SAS Institute Inc., Cary NC. 1985.

20) Stoffel W, Chu F, Ahrens EH Jr. Analysis of long chain fatty acids by gas chromatography
: Micromethod for preparation of methyl esters. Anal. Chem., $31: 307-308.1959$.

21) Takase $\mathrm{S}$, Morimoto A, Nakanishi M, Muto $\mathrm{Y}$. Long-term effect of medium-chain tri. glyceride on hepatic enzymes catalyzing lipogenesis and cholesterogenesis in rats. J. Nutr. Sci. Vitaminol., $23: 43-51.1977$.

22) Takase $S$, Hosoya N. Effect of dietary medium chain triglyceride on lipogenic enzyme activity in rat liver. J. Nutr. Sci. Vitaminol., $32: 219$ 227. 1986.

23) Takeda $Y$, Suzuki F, Inoue H. Methods Enzymol. 13 : 153-160. 1969.

24) Triscari J, Hamilton JG, Sullivan AC. Comparative effects of saturated and unsaturated lipids on hepatic lipogenesis and cholesterogenesis in vivo in the meal-fed rat. J. Nutr., $108: 815-825.1978$.

25) Wiley JH, Leveille GA. Metabolic consequences of dietary medium-chain trigly cerides in the rat. J. Nutr., 103:829-835. 1973. 
単一の脂肪酸（カプリル酸, カプロン酸, ラウリン酸, オレイン酸) からなるトリアシルグリセロールの給与がラット肝臓および 脂肪組織における脂肪酸合成関連酵素活性に及ぼす影響

\author{
鳥居伸一郎・黄 星九・松井 徹・矢野秀雄 \\ 京都大学農学部, 京都市左京区 606-01
}

\begin{abstract}
飼料中に添加した中鎖脂肪酸トリアシルグリセロール（MCT）における銷長の違いが成長中ラットの 脂肪酸合成関連醉素活性に及ぼす影響について検討した８週龄のウィスター系雄ラットを 4 グループ に分け, それぞれ単一の脂肪酸（カブリル酸; C8：0, カプロン酸; C 10:0, ラウリン酸; C 12:0, オレ

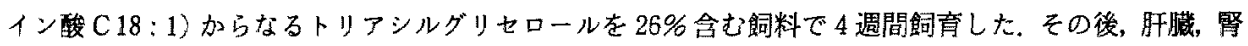
周囲脂肪組織, 副こう丸脂肪組織を採取し, 脂肪酸合成関連酵素であるグルコース-6-リン酸脱水素酵素 (G-6-PDH)，クエン酸開裂醉素（CCE）およびリンコ酸醉素（ME）の各活性を測定した，C8:0区は C 10：0区より李肝臓における G-6-PDH および CCE 活性が有意に高かった. また C8：0区と C 18:1 区は朋臟に括いて同程度の醉素活性を示した。腎周囲脂肪組織において, C 8：0区の G-6-PDH 活性お よび ME 活性は他の 3 区と比較して高加ったが、CCE 活性は C 10:0区およびC 12:0区よりあ低かっ た、副こう丸脂肪組織においては, C8:0区の G-6-PDH 活性および $\mathrm{ME}$ 活性が C $12: 0$ 区に対して低 かった．また腎周囲脂肪組織中のトリアシルグリセロールの脂肪酸組成を調へたところ，C10：0区およ び C12：0区ではそれぞれC 10:0，C12:0の脂肪酸がかなり存在したのに対し，C8：0区の脂肪組織か らはC8:00脂肪酸はほとんど険出されなかった. 以上の結果から, 飼料源としてのC10:0およびC 12:0の脂肪酸は，脂肪酸合成に及ぼす影響の点で，C8:0 とはかなり異なる中銷脂肪酸であると考え られた。
\end{abstract}

日畜会報, 67 (5) : 430-438, 1996 